\title{
Increased prevalence of coeliac disease in diabetes
}

\author{
M MÄKI, O HÄLLSTRÖM, T HUUPPONEN, T VESIKARI, AND J K VISAKORPI \\ Departments of Paediatrics and Microbiology, Tampere University Central Hospital, Tampere, Finland
}

SUMmARY A total of 215 diabetic children were screened for coeliac disease by determination of class specific serum reticulin antibody. Nine children were positive for reticulin antibody and all underwent biopsy of the small intestine. Four new cases of coeliac disease were found; all of these children had IgA reticulin antibody. Two of three other children with a low titre of IgA reticulin antibody had partial villous atrophy. It was concluded that IgA class reticulin antibody was a good marker of coeliac disease in diabetic children. The prevalence of coeliac disease in these children was 1:43 (including one previously diagnosed case) and we suggest that diabetic children be screened routinely for reticulin antibody.

Coexistence of coeliac disease and juvenile diabetes mellitus has been described in several reports. ${ }^{1-4}$ Although both Visakorpi ${ }^{2}$ and Thain et al ${ }^{3}$ considered this association to be more frequent in children than would be expected to occur by chance alone, this is not generally accepted and according to Walsh $\mathrm{et} \mathrm{al}^{4}$ coeliac disease is no more frequent in diabetics than in the general population.

Malabsorption associated with coeliac disease may lead to lability of diabetes and thus complicate treatment. Moreover, the standard diet for diabetic children includes large quantities of long acting carbohydrates (that is, gluten-containing cereals) which undoubtedly provoke coeliac disease. Therefore, even for the management of patients with diabetes mellitus alone, it is important to recognise coexisting coeliac disease as early as possible.

We have recently shown that serum IgA class reticulin antibody is both a sensitive and specific indicator of coeliac disease in children. ${ }^{5}$ Using reticulin antibody as a screening test we have tried to establish the prevalence of coeliac disease in our diabetic patients.

\section{Patients and methods}

All 215 diabetic children attending the paediatric outpatient clinic at this hospital were screened. Their mean age at the end of the study was $12 \cdot 3$ years, with a range of 3 to 18 years. The mean age at the diagnosis of diabetes mellitus was 7.2 years. A serum sample for reticulin antibody determination was collected from each patient at routine clinic attendances over a period of 12 months.
Reticulin antibody was determined using indirect immunofluorescence with unfixed cryostat sections. of rat kidney and liver as antigens. The sera were first tested at a dilution of 1:50 and 1:100. Polyvalent fluorescein-conjugated goat antiserum to human total immunoglobulins (Kallestad, USA) was used in the immunofluorescent screening test. If positive, the titre of the serum was determined with fluorescein-conjugated monospecific swine antihuman IgG and IgA (Orion Diagnostica, Finland). The fluorescein-protein molar ratio for the antisera was about 3 , and the working dilution was $1: 80$. Sections were examined by fluorescent incident light microscopy and the test was considered positive if a characteristic $R_{1}$ reticulin antibody pattern was found. ${ }^{6}$

In our previous study serum IgA class reticulin antibody was found in 28 of $29(97 \%)$ children with flat small bowel mucosa and, in low titre, in four of $245(2 \%)$ children with normal or nearly normal mucosa. Thus the sensitivity of the immunofluorescent test for $\operatorname{IgA}$ reticulin antibody in the detection of flat small bowel mucosa was $97 \%$, with a $98 \%$ specificity and an $88 \%$ positive predictive value. ${ }^{5}$ The corresponding figures for IgG class reticulin antibody in this study were $59 \%, 97 \%$, and $71 \%$, respectively. ${ }^{5}$

All patients found positive for reticulin antibody underwent small bowel biopsy, carried out with a paediatric size Watson capsule. Small bowel biopsy was also performed in eight reticulin antibody negative children with diabetes in whom coeliac disease was suspected on clinical grounds.

Informed consent was obtained from the parents and the children before small bowel biopsy. 
Table 1 Clinical characteristics of nine children with diabetes mellitus (DM) and positive serum reticulin antibody (RA)

\begin{tabular}{|c|c|c|c|c|c|c|c|}
\hline \multirow{2}{*}{$\begin{array}{l}\text { Case } \\
\text { No }\end{array}$} & \multirow[t]{2}{*}{ Sex } & \multicolumn{2}{|c|}{$R A$ titre } & \multirow{2}{*}{$\begin{array}{l}\text { Age at } \\
\text { biopsy } \\
\text { (years) }\end{array}$} & \multirow{2}{*}{$\begin{array}{l}\text { Age at } \\
\text { diagnosis of } D M \\
\text { (years) }\end{array}$} & \multirow{2}{*}{$\begin{array}{l}\text { Histological } \\
\text { findings of the } \\
\text { intestinal mucosa }\end{array}$} & \multirow{2}{*}{$\begin{array}{l}\text { Clinical } \\
\text { symptoms }\end{array}$} \\
\hline & & $\lg G$ & $\lg A$ & & & & \\
\hline 1 & $\mathbf{F}$ & $1: 5(x)$ & $1: 1(x)$ & $16 \cdot()$ & $9 \cdot 8$ & Flat & Delayed puberty \\
\hline 2 & $\mathrm{~F}$ & - & $1: 4(x) 0$ & 11.9 & $6 \cdot 6$ & Flat & Osteoporosis, arthralgia \\
\hline 3 & $\mathbf{M}$ & $1: 100$ & $1: 1000$ & $5 \cdot 8$ & $1 \cdot 3$ & Flat & Arthralgia, protruding abdomen \\
\hline 4 & $\mathbf{F}$ & $1: 200$ & $1: 8000$ & 9.9 & $8 \cdot 5$ & Flat & Protruding abdomen \\
\hline 5 & $\mathbf{F}$ & - & $1: 1(0)$ & $3 \cdot 9$ & $3 \cdot 7$ & Slight changes & None \\
\hline 7 & $\mathrm{M}$ & - & $1: 1(x)$ & $15 \cdot 6$ & $3 \cdot 7$ & Normal & None \\
\hline 8 & $\mathbf{M}$ & $1: 2(k)$ & - & $16 \cdot 6$ & $13 \cdot 5$ & Normal & None \\
\hline 9 & $F$ & $1: 200$ & - & $14 \cdot 3$ & 6.2 & Normal & None \\
\hline
\end{tabular}

\section{Results}

Reticulin antibody was found in the sera of nine of the $215(4 \%)$ children with diabetes mellitus. Three children had both $\operatorname{IgG}$ and $\operatorname{IgA}$ class reticulin antibodies, four had IgA class only, and two IgG class only. The results of small bowel biopsies and main clinical features in these children are summarised in Table 1.

Flat intestinal mucosa were found in four children; all had $\operatorname{IgA}$ class reticulin antibody and three had a high (1:1000 to $1: 8000)$ titre. Three of the four children also had IgG class reticulin antibody. Two children had minor changes (partial villous atrophy) in the intestinal mucosa; both also had a low titre of IgA reticulin antibody in serum. In the three remaining patients the histological findings in intestinal mucosa were normal. One of these three children had a low titre of $\operatorname{IgA}$ reticulin antibody and two had $\mathrm{IgG}$ reticulin antibody only.

The four diabetic children with flat intestinal mucosa were treated with gluten free diet. Serum reticulin antibody titres rapidly decreased in all four and became negative within one year (Table 2). Two

Table 2 Serum reticulin antibody $(R A)$ in diabetic children with flat intestinal mucosa before and after treatment with gluten free diet

\begin{tabular}{|c|c|c|c|c|c|}
\hline \multirow{3}{*}{$\begin{array}{l}\text { Case } \\
\text { No }\end{array}$} & \multirow{3}{*}{$\begin{array}{l}R A \\
\text { immunoglobulin } \\
\text { class }\end{array}$} & \multicolumn{4}{|l|}{$R A$ titre } \\
\hline & & \multirow{2}{*}{$\begin{array}{l}\text { Before } \\
\text { treatment }\end{array}$} & \multicolumn{3}{|c|}{ After treatment (months) } \\
\hline & & & 3 & 6 & 12 \\
\hline 1 & $\begin{array}{l}\operatorname{IgG} \\
\operatorname{IgA}\end{array}$ & $\begin{array}{l}1: 500 \\
1: 100\end{array}$ & $1: 100$ & $1: 200$ & - \\
\hline 2 & $\begin{array}{l}\text { IgG } \\
\text { IgA }\end{array}$ & $\frac{-}{1: 4000)}$ & $\mathrm{nt}$ & $\begin{array}{l}1: 50 \\
1: 1(0)\end{array}$ & - \\
\hline 3 & $\begin{array}{l}\text { IgG } \\
\text { IgA }\end{array}$ & $\begin{array}{l}1: 1(0) \\
1: 1(0)\end{array}$ & - & - & - \\
\hline 4 & $\begin{array}{l}\text { IgG } \\
\text { IgA }\end{array}$ & $\begin{array}{l}1: 2(x) \\
1: 8(x)(0)\end{array}$ & $\begin{array}{l}1: 100 \\
1: 100\end{array}$ & - & - \\
\hline
\end{tabular}

of the four children underwent a second biopsy: the Figure shows the histological appearance of the mucosa of one patient initially (IgG reticulin anti-

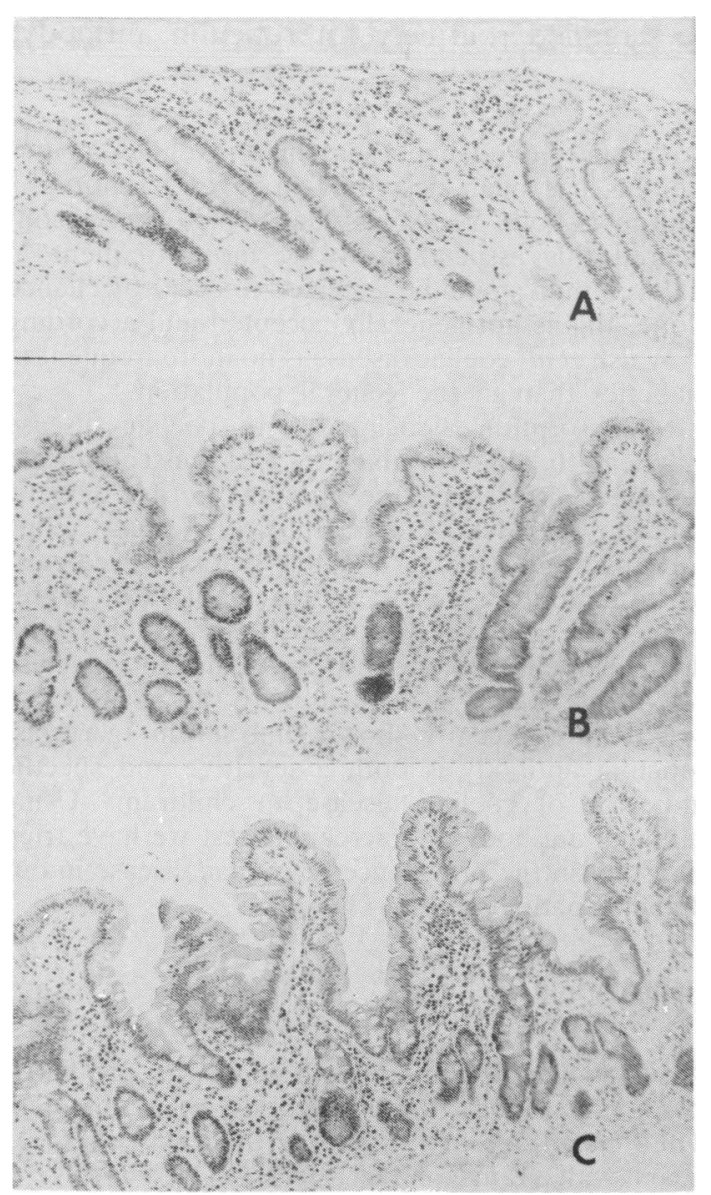

Figure Small bowel histology in a diabetic child (case 2 in Tables 1 and 2) positive for IgA class reticulin antibody before treatment with gluten free diet $(A)$ and after treatment at 6 months $(B)$ and 12 months $(C)$. 
body negative, IgA reticulin antibody 1:4000) and after 6 months (IgG reticulin antibody 1:50, IgA reticulin antibody $1: 100$ ) and 12 months (reticulin antibody negative) on a gluten free diet. The other child who underwent a follow up biopsy showed similar recovery of small intestinal mucosa, although in both cases some histological changes were still found after one year on a gluten free diet.

The two children (cases 5 and 6 in Table 1) with low $\operatorname{IgA}$ reticulin antibody titres and with slight partial villous atrophy were not put on a gluten free diet and will be followed further.

In retrospect, all four children with flat mucosa had some symptoms (Table 1) that could be attributed to coeliac disease but none had clinical symptoms of malabsorption or diarrhoea. Nor had they had any symptoms suggesting malabsorption in infancy, and their well baby clinic weight and height curves were normal.

No new cases of coeliac disease were found among the eight reticulin antibody negative children who underwent biopsy on clinical grounds.

One child on a gluten free diet among the 215 diabetics was known to have coeliac disease and was reticulin antibody negative at the time of the study. As the present survey detected at least four additional cases the prevalence of coeliac disease among these diabetic children was at least 1:43.

\section{Discussion}

We have recently shown that $\operatorname{IgA}$ reticulin antibody forms a sensitive and specific indicator of untreated coeliac disease in children. ${ }^{5}$ It is essential, however, that immunofluorescent test conditions are optimised as the reticulin antibody titres may be 10 to 100 times higher than values previously described in coeliac disease. ${ }^{7-9}$ In the present report we have used the improved method to screen for coeliac disease in 215 children with diabetes mellitus and found four previously undiagnosed diabetics.

These four children with small, flat intestinal murosa are believed to have coeliac disease, although the European Society for Paediatric Gastroenterology and Nutrition criteria ${ }^{10}$ with gluten challenge were not fulfilled. Other causes of small, flat intestinal mucosa in this age group are extremely rare in our country. A control biopsy in two of the children and the decline of serum reticulin antibody during gluten free diet support the diagnosis. The value of reticulin antibody for screening is emphasised by the fact that coeliac disease was not diagnosed among the eight children with negative serum reticulin antibody who also underwent small intestinal biopsy.
Reticulin antibody titres 1:5 to 1:20 have been described in diabetic children ${ }^{9}$ and it has been claimed that these result from transient mucosal alterations in the past such as atopic gastroenteropathy, cows' milk intolerance, and diarrhoea. We believe, however, that these are unlikely explanations in our patients with positive reticulin antibody and flat intestinal mucosa. Our patients had titres, particularly of $\operatorname{IgA}$ class reticulin antibody, which we have found to be highly disease specific. ${ }^{5}$ Out of 1584 children tested for reticulin antibody we have never found $\operatorname{IgA}$ reticulin antibody in titres higher than 1:100 except in those with coeliac disease.

The present study confirms the common association between coeliac disease and diabetes mellitus in children. The prevalence of coeliac disease among children with diabetes $(2.3 \%)$ is higher than that reported by Visakorpi $(1 \%)^{2}$ or Thain et al $(1.5 \%),{ }^{3}$ and much higher than in the general paediatric population. Although the higher prevalence in our study may be explained by the active search for coeliac disease with a sensitive serological marker, we believe that this figure may represent a minimum. The true prevalence may be established only by performing small bowel biopsies on all children with diabetes mellitus. Even among our patients the actual prevalence of coeliac disease may be higher since there is a possibility that the IgA reticulin antibody positive diabetic children with small intestinal mucosal damage classified as slight partial villous atrophy will later turn out to have coeliac disease. The close association between these disorders is probably explained on genetic grounds as both diseases have an association with HLA B8 and DR3 antigens. " 12

We conclude that all diabetic children (even those without abdominal symptoms) should be regularly followed for the appearance of IgA reticulin antibody to allow for early small bowel biopsy and diagnosis and treatment of coeliac disease.

This study was supported by the Emil Aaltonen foundation.

\section{References}

1 Thompson MV. Heredity, maternal age and birth order in etiology of celiac disease. Am J Hum Genet 1951;3:159-66.

2 Visakorpi JK. Diabetes and cocliac disease. Lancet 1969;ii: 1192.

3 Thain ME. Hamilton JR. Ehrlich RM. Coexistence of diabetes mellitus and celiac discase. J Pediatr 1974:85:527-9.

+ Walsh CH, Cooper BT. Wright AD. Malins JM. Cooke WT. Diabetes mellitus and cocliac disease: a clinical study. $Q J$ Med 1978:47:89-100.

5 Mäki M. Hällström O, Vesikari T. Visakorpi JK. Evaluation of a scrum IgA class reticulin antibody test for the detection of childhood celiac disease. $J$ Pediatr 1984: in press.

' Rizzetto M. Doniach D. Types of 'reticulin' antibodies detected in human sera by immunofluorescence. J Clin Pathol 1973:26:841-51. 
742 Mäki, Hällström, Huupponen, Vesikari, and Visakorpi

7 Scah PP, Fry L, Holborow EJ, et al. Antireticulin antibody: incidence and diagnostic significance. Gut 1973:14:311-5.

${ }^{8}$ Rizzetto M, Bonino F. Pera A. Barbera C. Santini B. Incidence and significance of different types of connective tissue antibodies in adult and pediatric gastroenterological disorders. Digestion 1978:17:29-37.

"Kokkonen J, Kiuttu J, Mustonen A. Räsänen O. Organ-specific antibodies in healthy and diabetic children and young adults. Acta Paediatr Scand 1982:71:223-6.

11 McNeish AS. Harms HK. Rey J. Schmerling DH, Visakorpi JK. Walker-Smith JA. The diagnosis of cocliac disease: a commentary on the current practices of the members of the European
Socicty for Paediatric Gastroenterology and Nutrition (ESPGAN). Arch Dis Child 1979:54:783-6.

"Verkasalo M. Tiilikainen A. Kuitunen P. Savilahti E. Backman A. HLA antigens and atopy in children with coeliac disease. Gut 1983:24:306-10.

12 Gutworth AG. Festenstein H. HLA genetic heterogeneity in diabetes mellitus. Br Med Bull 1978:34:285-9.

Correspondence to Dr M Mäki. Department of Clinical Sciences. University of Tampere, 33520 Tampere 52. Finland.

Received 12 April 1984 